\title{
As Eleições de 2016 em Umuarama: conjuntura das candidaturas à Prefeitura Municipal.
}

\section{Rafael Egidio Leal e Silva ${ }^{1}$}

- Enviado em 15/09/2016

- Aprovado em 18/09/2016
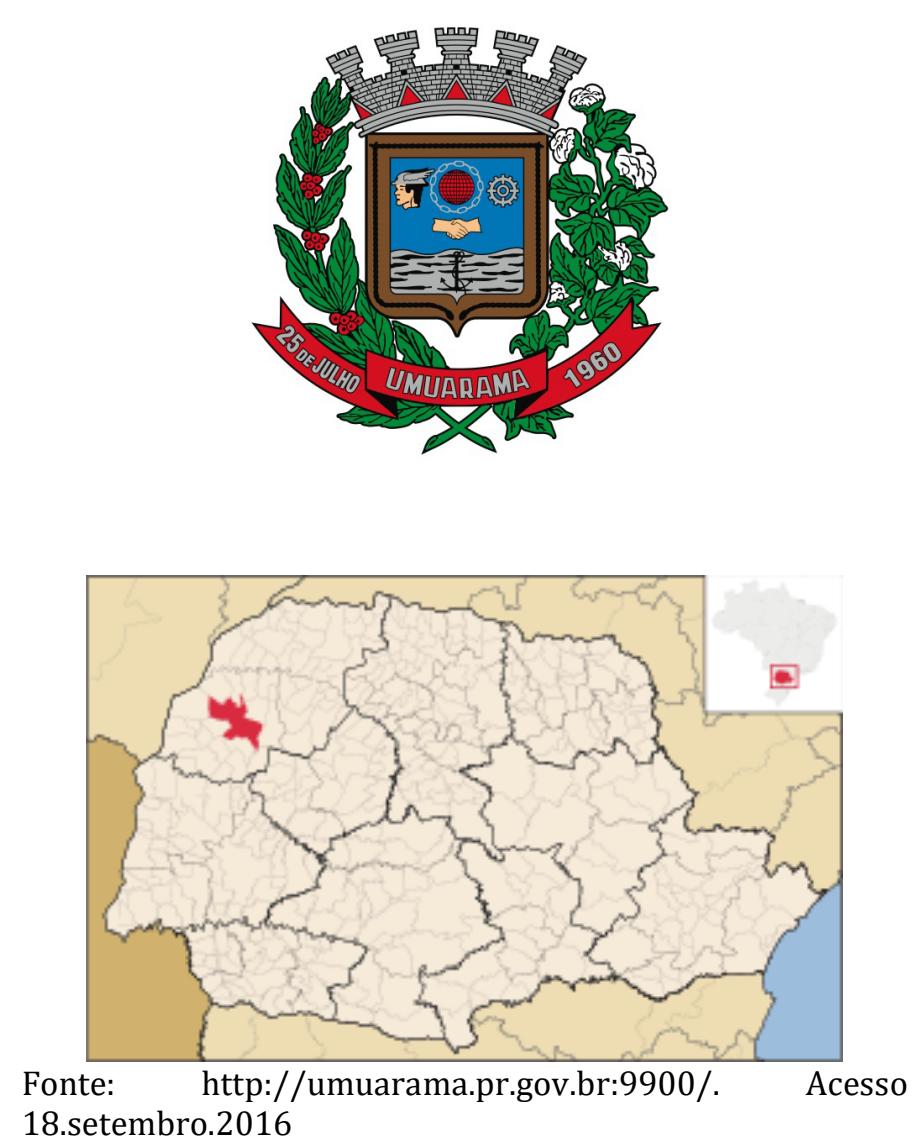

1 Graduado em Ciências Sociais - Licenciatura (2008) pela Universidade Estadual de Maringá. É Mestre em Psicologia (2012) pela mesma Universidade. Atualmente é Docente RSC-III do Ensino Básico, Técnico e Tecnológico, atuando no eixo tecnológico "Ciências Humanas e suas tecnologias" na área de conhecimento de Sociologia no Instituto Federal do Paraná - Campus Umuarama. E-mail: rafael.silva@ifpr.edu.br 


\title{
As Eleições de 2016 em Umuarama-PR: conjuntura das candidaturas à Prefeitura Municipal.
}

\author{
Rafael Egidio Leal e Silva
}

Umuarama, localizada no extremo noroeste do Estado do Paraná, é uma cidade de médio porte com população estimada em 109.132 habitantes. Distante 580 quilômetros da capital Curitiba, e a cerca de 100 quilômetros do Paraguai, trata-se, portanto, de uma cidade da região de fronteira do Estado brasileiro.

No tocante ao pleito eleitoral de 2016, Umuarama contará com 77.467 eleitores, sendo que deste total são aproximadamente $46,5 \%$ de homens, e 53,3\% de mulheres. Nas estatísticas eleitorais chama a atenção o fato da maior parte do eleitorado ter o Ensino Fundamental incompleto, com 25,5\%, e Ensino Fundamental completo com 8,47\%. Analfabetos e pessoas que "leem e escrevem" somam aproximadamente 14\%. Uma alta parcela do eleitorado umuaramense não tem o Ensino Médio Completo, com 22,56\%, e completaram este grau de Ensino 18,11\% do eleitorado. Eleitores com Ensino Superior somam 6,34\%, e que ainda não completaram este grau de ensino perfazem 4,99\% do eleitorado.

São 05 candidatos a prefeito e 131 candidatos a vereador neste ano de 2016 (que disputam 10 vagas na câmara local). 0 pleito de 2012 contou com 04 candidatos a prefeito e 137 candidatos a vereador. As candidaturas de vereadores estão agrupadas nos seguintes grupos de coligação: 1) Aliança por Umuarama (PMDB /PDT / PR / PMB / PROS /PRB /PT do B /PSL /SD /PSDB); 2) Umuarama em boas mãos (PRP / PTB / PPL); 3) Honestidade para trabalhar (PPS /PSC /PSD /PHS); 3) Participação popular para acertar (PSB /PSDC /PTN); 4) Aliança por Umuarama (DEM / PTC); 5) Partido Verde, PV; 6) Partido dos Trabalhadores, PT; 7) Partido da Mobilização Nacional, PMN.

A coligação “Aliança por Umuarama” (PMDB, PDT, PR, PMB, PROS, PRB, PT do B, PSL, SD, PSDB, DEM, PTC) tem como candidato a prefeito Antônio Carlos Fávaro (PDT), apoiado pela atual gestão. Este candidato já ocupou o cargo de secretário de Meio Ambiente e Agricultura do município. Disputa a prefeitura pela primeira vez, tendo como candidato a vice-prefeito Wilson Simões (PTC), que já foi vereador (1993 a 1996), Secretário de Serviços 
Públicos, de Indústria e Comércio e de Saúde da cidade. Além do apoio do atual prefeito Moacir Silva (PDT), importante empresário do setor imobiliário da cidade, contam com o apoio do ex-prefeito e atualmente deputado estadual Fernando Scanavaca, além do deputado federal Osmar Serraglio, congregando as lideranças políticas locais.

O empresário Celso Luiz Pozzobom (PSC) é o candidato da coligação “Umuarama melhor pra você" (PSC, PSB, PSD, PSDC, PTN, PP, PPS, PHS). 0 candidato já ocupou uma cadeira na Câmara de Vereadores da cidade, entre 1997 e 2004. Já ficou em segundo lugar na disputa pela prefeitura municipal em 2008. Seu candidato a vice-prefeito é Hermes Pimentel (PSDC), que tem origem humilde, e já foi vereador em 2008 e 2012. Interessante ressaltar que Pozzobom declarou bens na ordem de $\mathrm{R} \$ 1.317,151,60$, e é o único doador de sua campanha.

O candidato do PT é o bancário Edilson José Gabriel, que teve atuação no sindicalismo local, além de ter concorrido a vereador. Seu candidato a vice-prefeito é Pedro Zanco, empresário e contador, com participação em diversos conselhos da cidade. Os dois estão em sua primeira candidatura a prefeitura.

O candidato do PV é o professor Antonio Carlos Rigobello. Já foi vereador na legislatura de 2004 a 2008. Seu candidato a vice-prefeito é Claudiney Herrero, o Ney do Lokão, empresário do setor de confecções e com atuação no sindicato patronal do comércio local. Chama a atenção a evolução patrimonial do candidato Rigobello: na eleição de 2008, declarou R\$ 475.000,00, e nesta eleição seus bens declarados somam R\$ 1.053.922,23, ou seja, uma variação patrimonial de $121,88 \%$.

Completando o quadro de disputa pela prefeitura o PMN tem como candidato Gilberto Narciso, funcionário público e empresário, que faz sua primeira disputa. Seu candidato a vice é Halisson Batista, instrutor de trânsito na cidade, que também faz sua primeira disputa eleitoral

Podemos notar que a prefeitura de Umuarama é disputada tanto por iniciantes do jogo eleitoral, quanto pelas forças políticas tradicionais da cidade, polarizando esta disputa e fazendo que o jogo político da cidade seja complexo e de interesse das ciências sociais. 